\title{
Effect of SARS-CoV-2 mRNA vaccination on ocular herpes simplex and varicella-zoster virus reactivation: should preventive antiviral treatment be given in known herpes patients
}

\author{
Carl P. Herbort Jr and loannis Papasavvas(i)
}

To the editor.

Herpesviruses, including herpes simplex virus 1 (HSV1) and varicella-zoster virus (VZV) are commensal viruses of humans since millenaries.

Close to $80 \%$ of adults in temperate countries are exposed to HSV-1 and this proportion reaches more than 97\% in case of VZV [1].

After primoinfection these viruses remain in a latent form in sensory neuronal ganglia. The colonisation of the ganglia, including the trigeminal ganglion, occurs by progression of the virus mainly within peptidergic neurons [2]. Latency is an active and complex immune mechanism where CD8-positive $\mathrm{T}$ cells play an important role [3]. Although mRNA vaccines stimulate CD8+ $\mathrm{T}$ cells it could be hypothesised that it might dysregulate latency mechanisms in the sensory nerve ganglions [4]. In case of sarcoidosis when $\mathrm{T}$ cells are monopolised in the granulomas there is rescue humoral compensation to control herpes viruses by polyclonal anti-herpes antibody activation [5]. In case of transient or prolonged dysfunction of the immune system by diverse causes, reactivation of the virus can occur. It then reinfects peripheral sites by travelling down neurons causing herpes labialis, dendritic keratitis, herpetic uveitis or shingles in case of VZV virus. A recent study reported 14/414 (3.4\%) cases of herpes simplex and varicella-zoster eruptions among cutaneous findings after mRNA-based vaccinations, a relatively large percentage [6]. However, no

\footnotetext{
* Correspondence: cph@herbortuveitis.ch

Inflammatory and Retinal Eye Diseases, Centre for Ophthalmic Specialised Care (COS), Rue Charles-Monnard 6, 1003 Lausanne, Switzerland
}

details were given on these patients. We recently reported on three cases of herpes zoster ophthalmicus (HZO) after mRNA anti-SARS-CoV-2 vaccinations (Moderna and Pfizer BioNTech respectively), 2 weeks after first dose vaccination in two patients and 2 weeks after a Pfizer Bio NTech booster vaccination in another patient who had undergone Covid-19 infection [7]. Non ocular varicella-zoster reactivations after mRNA vaccinations have recently been reported [8].

\section{Case report}

We recently examined a 53-year-old man, treated in the past for herpes kerato-uveitis OD that had been inactive for 18 months without treatment. Five days after the second dose of Moderna vaccine, he presented with a severe flare-up of a granulomatous hypertensive uveitis in his right eye with numerous granulomatous KPs and an increased pressure of $41 \mathrm{mmHg}$ (Fig. 1). Under valacyclovir (500 mg QID), 0.1\% dexamethasone drops QID and dorzolamide hydrochloride - timolol maleate eye drops BID, pressure normalised within 6 days, laser flare photometry (LFP) flare, decreased from $19.4 \mathrm{ph} / \mathrm{ms}$ to $13.2 \mathrm{ph} / \mathrm{ms} 3$ weeks later and granulomatous KPs had almost disappeared. Because of fluctuating IOP and LFP values thereafter, Valacyclovir (500 mg BID), Acetazolamide $(125 \mathrm{mg} /$ day), dorzolamide hydrochloride BID and dexamethasone $0.1 \%$ eye drops once daily had to be maintained until the last recorded follow-up two and a half months later with LFP values of $12.2 \mathrm{ph} / \mathrm{ms}$ and an IOP value of $16 \mathrm{mmHg}$.
Springer Open (c) The Author(s). 2021 Open Access This article is licensed under a Creative Commons Attribution 4.0 International License, which permits use, sharing, adaptation, distribution and reproduction in any medium or format, as long as you give appropriate credit to the original author(s) and the source, provide a link to the Creative Commons licence, and indicate if changes were made. The images or other third party material in this article are included in the article's Creative Commons licence, unless indicated otherwise in a credit line to the material. If material is not included in the article's Creative Commons licence and your intended use is not permitted by statutory regulation or exceeds the permitted use, you will need to obtain permission directly from the copyright holder. To view a copy of this licence, visit http://creativecommons.org/licenses/by/4.0/. 


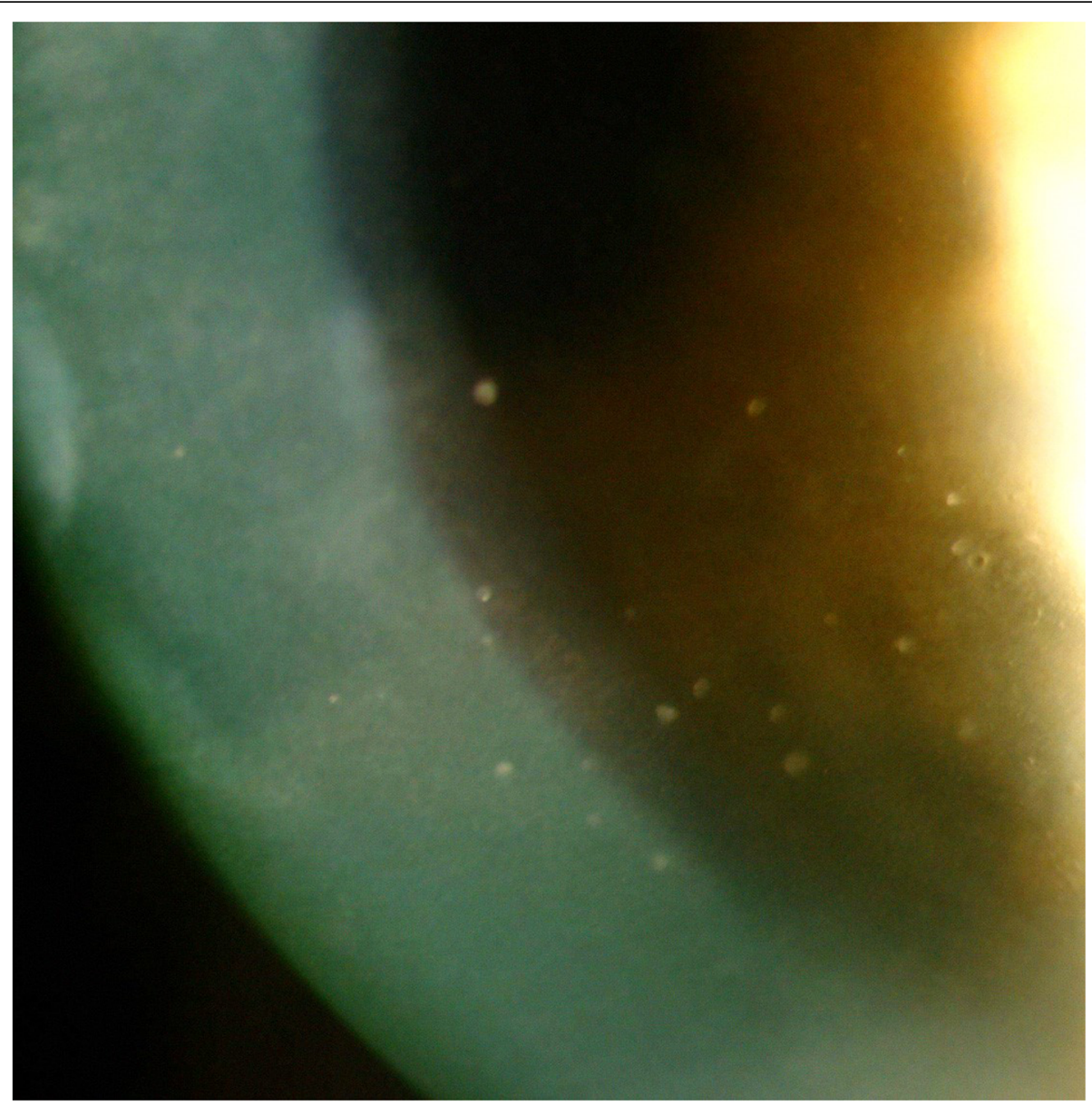

Fig. 1 Herpetic kerato-uveitis: Numerous granulomatous KPs on the endothelium

It is difficult to know whether this episode was purely inflammatory. Even if this was the case dual corticosteroid and antiviral therapy has to be given in such circumstances.

Since this case, we advise patients having had several herpes uveitis episodes to remain under valacyclovir therapy during vaccination despite quiet uveitis to avoid potential reactivation, which was undertaken for two patients so far.

\section{Comment}

HSV-1 and VZV infections can cause substantial ocular morbidity. Since the availability of efficient antiviral agents, management of eye disease caused by herpes viruses are successfully treated in most cases and complications have been reduced [9]. However, each new episode can harm eye structures. Moreover, some herpes reactivations such as acute retinal necrosis are much more deleterious and their management much more difficult. Therefore, in patients having presented herpesvirus infections in the past, the question can be raised whether preventive antiviral therapy should be recommended, possibly at least in high-risk patients, in case of mRNA vaccination after discussing it with the patient.

\section{Abbreviations}

HSV-1: Herpes simplex virus 1; VZV: Varicella-zoster virus; CD8+ T cells: Cluster of differentiation 8 positive T cells; mRNA: Messenger ribonucleic acid; HZO: Herpes zoster ophthalmicus

\section{Acknowledgements}

$\mathrm{n} / \mathrm{a}$.

Authors' contributions

All authors contributed equally in writing and editing the article.

\section{Funding}

We did not receive any funding.

Availability of data and materials

For data, please refer to corresponding author.

\section{Declarations}

Ethics approval and consent to participate

This brief report has been performed in accordance with the ethical standards as laid down in 1964 by the declaration of Helsinki and its later amendments. Anonymous case reports are approved by the ethics 
committee of our institution (EC-COS-MTC) as long as written consent is obtained from the patients.

\section{Consent for publication}

Consent was signed by the patient.

\section{Competing interests}

No conflict of interest.

Received: 23 June 2021 Accepted: 29 August 2021

Published online: 17 September 2021

\section{References}

1. Olsson J, Kok E, Adolfsson R, Lövheim H, Elgh F (2017) Herpes virus seroepidemiology in the adult Swedish population. Immun Ageing 14(1):10, https://doi.org/10.1186/s12979-017-0093-4. eCollection 2017

2. Herbort CP, Weissmann SS, Payan DG (1989) Role of peptidergic neurons in ocular herpes simplex infection. FASEB J 3(13):2537-2541. https://doi.org/1 0.1096/fasebj.3.13.2553522

3. St Leger AJ, Hendricks RL (2011) CD8+ T cells patrol HSV-1 infected trigeminal ganglia and prevent viral reactivation. J Neuro-Oncol 17(6):528534. https://doi.org/10.1007/s13365-011-0062-1

4. Perng $\mathrm{GC}$, Jones $\mathrm{C}$. Towards an understanding of the herpes simplex virus type 1 latency-reactivation cycle

5. Papasavvas I, Gehrig B, Herbort CP Jr (2021) The comparative value of serum angiotensine converting enzyme (ACE) and lysozyme and the use of polyclonal antibody activation in the work-up of ocular sarcoidosis. Diagnostics (Basel) 11(4):608. https://doi.org/10.3390/diagnostics11040608

6. McMahon DE, Amerson E, Rosenbach M, Lipoff JB et al (2021) Cutaneous reactions reported after Moderna and Pfizer Covid-19 vaccination: a registery-based study of 414 cases. J Am Acad Dermatol 85(1):46-55. https://doi.org/10.1016/j.jaad.2021.03.092 Epub 2021 Apr 7

7. Papasavvas I, de Courten C, Herbort CP Jr. Varicella-zoster virus reactivation causing herpes zoster ophthalmicus (HZO after SARS-CoV-2 vaccination : 3 cases. J Ophthalmic Inflamm Infect 2021; in print

8. Rodriguez-Jimenez P, Chicharro P, Cabrera LM, Segui M, Morales-Caballero A, Llamas-Velasco M, Sanchez-Perez J (2021) Varicella-zoster virus reactivation after SARS-Cov-2 BNT162b2 mRNA vaccination: report of 5 cases. JAAD Case Rep 12:58-59. https://doi.org/10.1016/j.jdcr.2021.04.014 Epub 2021 Apr 24

9. Herbort CP, Buechi ER, Piguet B, Zografos L, Fitting P (1991) High-dose oral acyclovir in acute herpes ophthalmicus: the end of the corticosteroid era. Curr Eye Res 10(Suppl):171-175. https://doi.org/10.3109/02713689109020375

\section{Publisher's Note}

Springer Nature remains neutral with regard to jurisdictional claims in published maps and institutional affiliations.

\section{Submit your manuscript to a SpringerOpen ${ }^{\circ}$ journal and benefit from:}

- Convenient online submission

- Rigorous peer review

- Open access: articles freely available online

- High visibility within the field

- Retaining the copyright to your article 